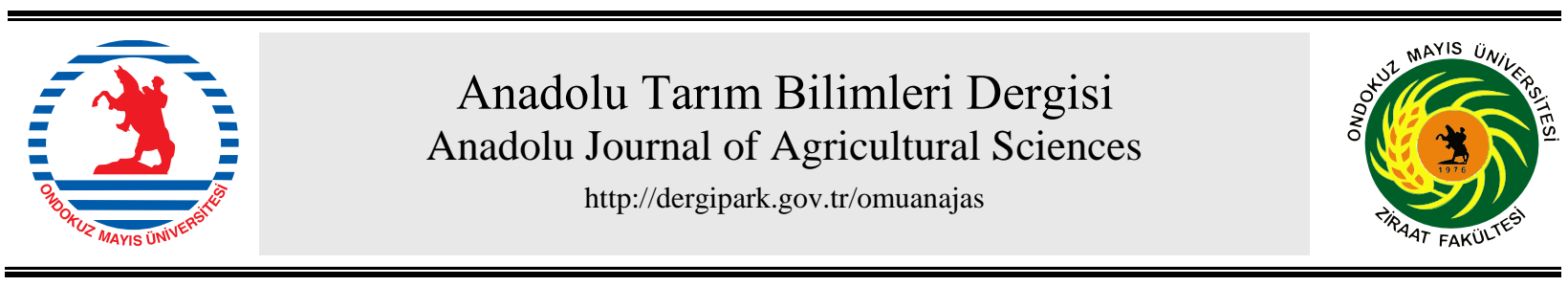

\title{
Araştırma/Research
}

Anadolu Tarım Bilim. Derg./Anadolu J Agr Sci, 36 (2021) ISSN: 1308-8750 (Print) 1308-8769 (Online) doi: 10.7161/omuanajas.870778

\section{Determination of growth models in organic lettuce cultivation}

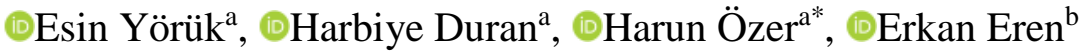 \\ ${ }^{a}$ Ondokuz Mayls University, Faculty of Agriculture, Department of Horticulture, Samsun, Turkey \\ ${ }^{b}$ The University of Ege, Bergama Vocational School, Department of Plant and Animal Production, İzmir, Turkey \\ *Sorumlu yazar/corresponding author: haruno@omu.edu.tr \\ Geliş/Received 29/01/2021 Kabul/Accepted 02/05/2021
}

\begin{abstract}
The present study was conducted to determine the quantitative effects of light and temperature on growth of organic lettuce (Lactuca sativa L. var. crispa). In order to create variations in lettuce cultivation, effect of two different wastes mushroom compost (Agaricus-AMS; Agaricus bisporus and Pleurotus-AMS; Pleurotus ostreatus) and vermicompost applications were investigated. Plant height, number of leaves, crown diameter, chlorophyll content (CCL) and leaf stomatal conductivity were measured as quality parameters for the lettuces. Significant differences were observed in the quality parameters related to the organic fertilization. A mathematical model has been developed to estimate the number of days (harvest time) required to produce lettuce with variation values generated by different organic fertilization $\left(r^{2}=0.99\right)$.
\end{abstract} Keywords: Lactuca sativa Light Temperature Modelling Greenhouse

\section{Organik Marul Yetiştiriciliğinde Büyüme Modellerinin Belirlenmesi}

\section{ÖZET}

$\mathrm{Bu}$ çalışma, organik marul (Lactuca sativa L. var. crispa) yetiştiriciliği üzerine sıcaklık ve 1şığın kantitatif etkilerinin belirlemesi amacıyla yürütülmüştür. Organik marul yetiştiriciliğinde, iki farklı atık mantar kompostu (Agaricus-AMS; Agaricus bisporus ve Pleurotus-AMS; Pleurotus ostreatus) ve solucan gübresi uygulamalarının etkisi incelenmiştir. Marullar için kalite parametreleri olarak bitki boyu, yaprak sayısı, taç çapı, klorofil içeriği (CCL) ve yaprak stoma iletkenliği ölçülü yapılmıştır. Anahtar Sözcükler: Lactuca sativa Iş1k Sicaklık Modelleme Sera Organik gübreleme ile ilgili kalite parametrelerinde önemli farklılıklar belirlenmiştir. Farklı organik gübrelemeyle $\left(r^{2}=0.99\right)$ üretilen varyasyon değerleri ile marul üretmek için gereken gün sayısını (hasat zamanı) tahmin etmek için matematiksel bir model geliştirilmiştir.

(C) OMU ANAJAS 2021 


\section{Introduction}

Lettuce is an annual vegetable among the most whose leaves are consumed vegetables in the world (Eşiyok 2012; Kibar, 2018). The lettuce (Lactuca sativa L.) has an important place in the economy (26 million tons) of world (FAO, 2019). Lettuce cultivated in the world for many years, like organic matter-rich soils. Organic matter in the soil accelerates the growth of lettuce and shortens the harvest time. However, excessive and unconscious nitrogenous chemical fertilizers are used to increase the accumulation of nitrates harmful to human health (Vural et al., 2000; Kibar, 2018). It is reported that inorganic fertilization causes three times more nitrate accumulation than organic fertilization in lettuce which is one of the most nitrate accumulation vegetables (Santamaria 2006; Özgen et al., 2011; Kibar, 2018). On the contrary, by using organic fertilizers, the physical and chemical structure of the soil can be improved by increasing the microorganism activities (Özer, 2016). For these and many different reasons, the use of organic fertilizers should be expanded in lettuce cultivation.

Among the organic fertilizers, the production and usage of vermicompost is increasing in recent years. Vermicompost is rich in plant nutrients, beneficial soil microorganisms, various enzymes, humus, organic matter and growth hormones (Garg and Gupta, 2009; Özkan et al., 2016; Kibar, 2018). It is widely used as organic fertilizer and soil conditioner in both organic and conventional agricultural production. It is known that, as a result of vermicompost application to soil, plant growth and soil properties are affected significantly and positively. It was determined that plant growth, yield, quality and nutrient contents of many vegetable species increased with vermicompost application (Kibar 2018). Another material that can be an organic plant nutrient is waste mushroom compost. These bees are materials rich in organic matter and some nutrients that are released after production in mushroom cultivation. (Pekşen and Yamaç 2016). For every $1 \mathrm{~kg}$ of mushroom, 3-5 kg of waste mushroom compost is released. In the light of these data, it can be say that 50 million tons / year waste mushroom compost will be released in the world (Singh et al., 2003; Pekşen and Yamaç, 2016). Waste mushroom compost is a valuable waste with its high water holding capacity, good drainage, rich in nutrient and organic matter, easy and abundant availability, low cost, easy to carry. However, its most important problem is its salt content, so this problem can be solved by using it in the open area waiting, washing and mixing with other materials (Pekşen and Yamaç, 2016).

Lettuce, especially greenhouses is grown all year round. Harvest time of lettuce varies depending on variety, cultural processes and ecological factors (Uzun 2007; Sarıbaş et al., 2018; Sarıbaş and Uzun 2019). Temperature and lighting are determinants in plant growth, depending on the growing period (Taiz and Zeiger 2008). The short post-harvest strength also brings some problems. To solve such problems, producers are planting gradually planting seedlings. Estimating the harvest time using several growth models can provide producers with many advantages, such as efficient use of greenhouse space and marketing strategies. The aim of this study is to investigate the effects of different environmental conditions (light and temperature) to determine some yield parameters of lettuce grown organically in two mushroom compost waste and vermicompost mediums and to develop a model in lettuce cultivation.

\section{Material and Method}

The present study was conducted at greenhouses of Ondokuz Mayıs University Agricultural Faculty Horticulture Department the years 2018. Experimental greenhouses are $6 \mathrm{~m}$ wide and $20 \mathrm{~m}$ long $\left(120 \mathrm{~m}^{2}\right)$.

These greenhouses have been cultivating organic for 17 years. cv. model lettuce variety (Lactuca sativa L. var. crispa) was used in the study. In the research, two different wastes mushroom compost (Agaricus-AMS; Agaricus bisporus and Pleurotus-AMS; Pleurotus ostreatus) and vermicompost (V) were used to provide plant nutrient elements to the soil. The waste mushroom composts were obtained from the mushroom house in the Kayagüney village of Samsun after the production. Vermicompost was obtained from a private company.

In the study, raised bed in the greenhouse with a width of $1.2 \mathrm{~m}$ and a height of $30 \mathrm{~cm}$ were prepared. Then, raised beds were divided into $80 \mathrm{~cm}$ long parcels. $40 \mathrm{~cm}$ width is left between parcels. In this study, Agaricus-AMS and Pleurotus-AMS and vermicompost were mixed to $20 \mathrm{~cm}$ depth of the parcels prepared to provide $3 \%$ (5.4 kg) organic matter to the soil. No application was made to the control parcels. Agaricus-AMS and Pleurotus-AMS waste composts were stored for 2 weeks before use.

Three dripper lines (with drippers $25 \mathrm{~cm}$ apart) were installed over each raised bed. Lettuce seedlings were planted at $25 \times 25 \mathrm{~cm}$ spacing on 12 October 2018. Soil samples were taken from each application of the greenhouse. Nutrients and organic matter contents of soil samples (Table 1) were then determined (Kacar and İnal, 2008). 
Table 1. Chemical characteristics of soil samples $(0-20 \mathrm{~cm})$ taken at the each applications.

Çizelge 1. Her uygulamada alınan toprak örneklerinin (0-20cm) kimyasal özellikleri.

\begin{tabular}{l|ccccccccccc}
\hline \multicolumn{1}{c}{ Treatment } & $\begin{array}{c}\mathrm{N} \\
\%\end{array}$ & $\begin{array}{c}\mathrm{OM} \\
\%\end{array}$ & $\mathrm{C} / \mathrm{N}$ & $\begin{array}{c}\mathrm{Fe} \\
(\mathrm{ppm})\end{array}$ & $\begin{array}{c}\mathrm{Cu} \\
(\mathrm{ppm})\end{array}$ & $\begin{array}{c}\mathrm{Zn} \\
(\mathrm{ppm})\end{array}$ & $\begin{array}{c}\mathrm{Mn} \\
(\mathrm{ppm})\end{array}$ & $\begin{array}{c}\mathrm{Na} \\
(\mathrm{ppm})\end{array}$ & $\begin{array}{c}\mathrm{K} \\
(\mathrm{ppm})\end{array}$ & $\begin{array}{c}\mathrm{Ca} \\
(\mathrm{ppm})\end{array}$ & $\begin{array}{c}\mathrm{Mg} \\
(\mathrm{ppm})\end{array}$ \\
\hline Control & 2.4 & 2.7 & 1.88 & 8189 & 3.1 & 48.2 & 742 & 630 & 2525 & 46623 & 5991 \\
Vermicompost & 10.6 & 10.2 & 0.79 & 8884 & 3.4 & 47.5 & 744 & 683 & 2600 & 46580 & 6100 \\
Agaricus-AMS & 10.0 & 11.3 & 0.71 & 7297 & 3.4 & 47.4 & 686 & 675 & 2573 & 52615 & 6260 \\
Pleurotus-AMS & 9.1 & 8.8 & 0.56 & 11952 & 5.7 & 47.2 & 751 & 598 & 2080 & 51723 & 5415 \\
\hline
\end{tabular}

Soil temperature $\left({ }^{\circ} \mathrm{C} ; 15 \mathrm{~cm}\right.$ depth) was made in the parcels (Vermicompost, Agaricus-AMS and PleurotusAMS) and air temperature $\left({ }^{\circ} \mathrm{C}\right)$ measurements (Table 2) in regular $(60$-minute periods) data were recorded with data recorders (KT100, Kimo, France). For all measurement hours, measurement values of both devices were compared and conversion factor (1 PAR; MJ m ${ }^{-2} \mathrm{~d}^{-1}=2400.16$ lux) was determined (Sarıbaş et al., 2018).

Table 2. Temperature $\left({ }^{\circ} \mathrm{C}\right)$, soil temperature, light intensity $\left(\mathrm{MJ} \mathrm{m}^{-2}\right.$ day $\left.^{-1}\right)$ and photoperiod values.

Çizelge 2. Sicaklık $\left({ }^{\circ} \mathrm{C}\right)$, toprak sıcaklı̆̆l, ışı şiddeti $\left(M J m^{-2}\right.$ gün $\left.^{-1}\right)$ ve fotoperiyod değerleri.

\begin{tabular}{lccc}
\hline & Mean & Max. & Min \\
\hline Temperature $\left({ }^{\circ} \mathrm{C}\right)$ & 11.73 & 20.97 & 4.75 \\
Soil temperature $\left({ }^{\circ} \mathrm{C}\right)$ & 14.02 & 22.45 & 8.11 \\
Light $\left(\mathrm{MJ} \mathrm{m}^{-2} \mathrm{day}^{-1}\right)$ & 0.73 & 2.04 & 0.05 \\
Photoperiod & 9.26 & 11 & 8 \\
\hline
\end{tabular}

Plant height (cm), number of leaves, crown diameter (cm), chlorophyll content (CCL), leaf stomatal conductivity $\left(\mathrm{mmol} \mathrm{m} \mathrm{m}^{-2} \mathrm{~s}^{-1}\right)$ of lettuce were measured during the growing period. Leaf stomatal conductivity was measured with a stomatal conductivity device (SC-1, Decogon Devices, Pullman, USA) between the hours 10.00 and 11.00 a.m. from all leaves of the lettuce and expressed as $\mathrm{mmol} \mathrm{m}^{-2} \mathrm{~s}^{-1}$. Leaf chlorophyll content was measured as leaf chlorophyll index (CCI) also between the hours 10.00 and 11.00 a.m. from all leaves of the lettuce with a chlorophyll meter (CCM-200, Opti-Sciences, Hudson, USA). Lettuce plants (9 plants of each replication) were removed from the soil and separated into root, stem and leaves. Roots were flashed with tap water to remove all the soil particles over them. Leafs, stems and roots were separately placed into small paper bags and dried in an oven (Venticell 55, Ecocell, MMM group, Germany) at $80 \square \mathrm{C}$ for 48 hours. Weight change method was used to decide whether or not the drying is complete. Fully dried leaf, stem and root samples were weighed with a digital scale (Table 3).

Experiments were conducted in a randomized block design with three blocks and with 9 plants in each replication. SPSS 17.0 statistical analysis program was used to evaluate the data obtained from the study. The differences between the means obtained were determined by test $\left(* \mathrm{P}<0.05,{ }^{*} * \mathrm{P}<0.01\right)$. Multiple regression analyses were performed with Microsoft Excel 2010 software and the resultant models were presented in 3-D graphs with Slide Write 7.0 software.

\section{Result and Discussion}

Significant differences were observed in quality parameters (plant height, crown diameter, leaf number, lettuce dry weight and stomatal conductance) between the growing periods $\left({ }^{*} \mathrm{P}<0.05,{ }^{* *} \mathrm{P}<0.01\right)$ (Table 3$)$. The highest plant height $(17.80 \mathrm{~cm})$ and leaf number (31.6) were obtained on plants grown in the Agaricus-AMS applications. The highest crown diameter $(23.28 \mathrm{~cm})$ and stomatal conductance $\left(248.92 \mathrm{mmol} \mathrm{m} \mathrm{m}^{-2} \mathrm{~s}^{-1}\right)$ were obtained on plants grown in the vermicompost applications. The highest lettuce dry weight $(5.01 \mathrm{~g})$ was obtained from Pleurotus-AMS application. The lowest plant height $(14.4 \mathrm{~cm})$, crown diameter $(19.08 \mathrm{~cm})$ and stomatal conductance $(103.63 \mathrm{mmol}$ $\mathrm{m}^{-2} \mathrm{~s}^{-1}$ ) were obtained from the Pleurotus-AMS, while the lowest leaf number was obtained from the control application. 
Nitrogen is an important element for plant growth and development. However, due to environmental pollution and high concentrations of nitrate accumulate in edible parts of leafy vegetables such as lettuce, especially if excessive nitrogen fertilizer is applied. Consuming these products can harm human health. In particular, it has been reported that the use of organic fertilizers reduces nitrate accumulation in lettuce and results in successful cultivation (Pavloua et al., 2007; Liu et al., 2014).

In a study conducted, it was reported that plant height values increased with waste mushroom compost application (Polat et al., 2004). In a study investigating the effect of beef and chicken manure compost on lettuce cultivation, it was determined that applied fertilizer type significantly $(\mathrm{P}<0.05)$ affected lettuce growth, yield and nutritional quality. As a result of this study, it was reported that lettuce can be grown successfully by using organic fertilizers. (Masarirambi et al., 2010). In our study in which similar results were obtained, it was determined that the amount of organic matter and nitrogen content increased and yield and quality values increased with organic fertilizer applications (Tablo 1; 3).

Table 3. Effects of different organic fertilizers on lettuce quality and harvest parameters compared to control.

Çizelge 3. Farklı organik gübrelerin kontrole göre marul kalite ve hasat parametrelerine etkisi.

\begin{tabular}{|c|c|c|c|c|c|c|}
\hline Treatment & $\begin{array}{l}\text { Plant height } \\
\text { (cm) }\end{array}$ & $\begin{array}{l}\text { Leaf } \\
\text { number }\end{array}$ & $\begin{array}{c}\text { Crown } \\
\text { diameter }(\mathrm{cm})\end{array}$ & $\begin{array}{c}\text { Lettuce dry } \\
\text { weight (g) }\end{array}$ & $\begin{array}{l}\text { Stomatal conductance } \\
\quad\left(\mathrm{mmol} \mathrm{m}^{-2} \mathrm{~s}^{-1}\right)\end{array}$ & $\begin{array}{c}\text { Chlorophyll } \\
\text { content (CCI) }\end{array}$ \\
\hline Control & $15.58 \mathrm{ab}$ & $27.89 \mathrm{~b}$ & $19.39 \mathrm{~b}$ & $3.55 \mathrm{~b}$ & $107.10 \mathrm{~b}$ & 5.98 \\
\hline Vermicompost & $16.77 \mathrm{ab}$ & $31.33 \mathrm{ab}$ & 23.28 a & $4.79 \mathrm{a}$ & $248.92 \mathrm{a}$ & 5.43 \\
\hline Agaricus-AMS & $17.80 \mathrm{a}$ & 32.67 a & 21.79 a & $4.98 \mathrm{a}$ & 238.75 a & 6.61 \\
\hline Pleurotus-AMS & $14.44 \mathrm{~b}$ & $28.67 \mathrm{ab}$ & $19.08 \mathrm{~b}$ & $5.01 \mathrm{a}$ & $103.63 \mathrm{~b}$ & 5.56 \\
\hline Pooled SEM & 1.52 & 2.39 & 1.87 & 0.81 & 6.88 & 0.91 \\
\hline Treatment & $* *$ & ** & $* *$ & $*$ & $*$ & N.S \\
\hline
\end{tabular}

A 'production period' model (Equation-1) was developed by using the variation values created from the different organic waste (Vermicompost, Agaricus-AMS and Pleurotus-AMS). Despite the significant differences between the growing periods, $\mathrm{r}^{2}$ was high (0.99). As a result of multiple regression analyses, the relationship of number of days from harvest (HT; day) with temperature $\left(\mathrm{T} ;{ }^{\circ} \mathrm{C}\right)$ and light intensity $\left(\mathrm{L} ; \mathrm{MJ} \mathrm{m}^{-2}\right.$ day $^{-1}$ ) was expressed with the following equation (Figure 1).

$$
\begin{aligned}
& H T=91.44-0.088 x T-11.23 \times L-0.076 \times T^{2}+3.42 \times L^{2} \ldots \ldots \ldots . . \\
& \mathrm{SE}=(11.17)^{* * *}(0.39)^{* * *}(0.49)^{* * *}(0.013)^{* * *}(0.16)^{* * *} \\
& r^{2}=0.99^{* * *},
\end{aligned}
$$

Where: HT is time from lettuce to harvest (day); $\mathrm{T}$ is daily average temperature $\left({ }^{\circ} \mathrm{C}\right)$; $\mathrm{L}$ is daily average light intensity $\left(\mathrm{MJ} \mathrm{m}^{-2}\right.$ day $\left.^{-1}\right)$; $\mathrm{SE}$ is standard error of coefficients and $\mathrm{r}^{2}$ is reliability coefficient of the equation. 


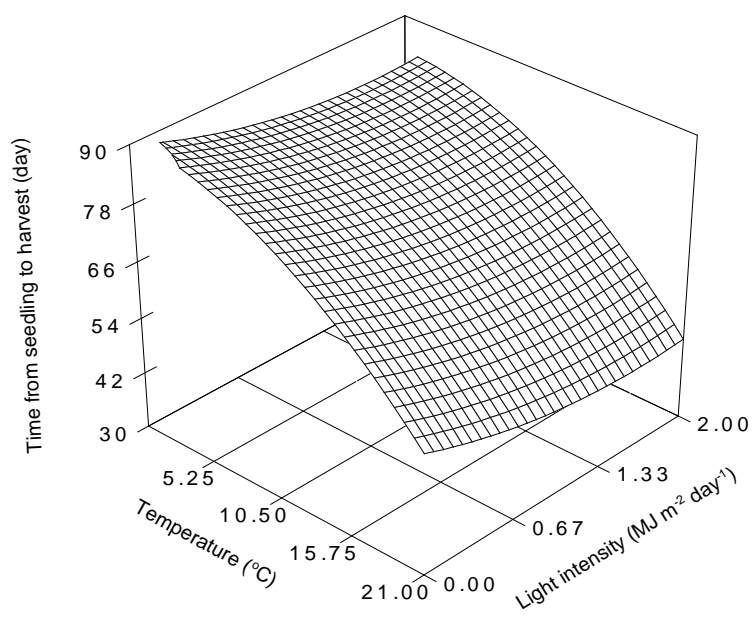

Şekil 1. Marulda hasat zamanının ışık ve sıcaklığa göre belirlenmesi.

Figure Determining the harvesting time of lettuce according to light and temperature.

1.

\section{Conclusion}

The findings will be used in organic lettuce production depending on changes in temperature and light intensity to determine and model the time from seedling to harvest (HT). These models can make significant contributions to the lettuce producers' planning of organic lettuce production.

Due to the good balance between temperature and light, lettuce was found to increase total dry weight, stomatal conductivity and leaf chlorophyll content. It is thought that the use of the model in organic lettuce growing systems in aquaculture will contribute to healthy and efficient plant growing by guiding the preferences of the producers.

\section{References}

Eşiyok, D., 2012. Kışlık ve yazlık sebze yetiştiriciliği. Meta Basım, Bornova/İzmir.

FAO., 2019. Crop production statistics. http://www.fao.org/faostat/en/\#data/QC, (access date: 13.11.2019)

Garg, V.K., Gupta, R., 2009. Vermicomposting of agro-industrial processing waste. Biotechnology for AgroIndustrial Residues Utilisation (Eds. Nigam PSN and Pandey A), Springer, Netherlands, pp. 431-456.

Kacar, B., İnal. A., 2008. Plant Analysis. Nobel Yayın No 1241, Ankara, 892p.

Kibar, B., 2018. Determination of the interrelationships among plant properties, some quality properties and elements in lettuce. International Journal of Agriculture and Wildlife Science, 4(2): 149-160.

Liu, C., Sung, W.Y., Chen, B.C., Lai. H.Y., 2014. Effects of Nitrogen Fertilizers on the Growth and Nitrate Content of Lettuce (Lactuca sativa L.). Int. J. Environ. Res. Public Health, 11(4):4427-4440.

Masarirambi, M.T., Hlawe, Ö.M., Oseni, O.T., Sibiya, T.E., 2010. Effects of organic fertilizers on growth, yield, quality and sensory evaluation of red lettuce (Lactuca sativa L.) 'Veneza Roxa'. Agriculture and Biology Journal of North America, 1(6): 1319-1324.

Özer, H., 2016. Organic tomato cultivation. International Journal of Agriculture and Wildlife Science, 2(1): 43-53.

Özgen, Ş., Şekerci, Ş., Karabıyık, T., 2011. Organik ve inorganik gübrelemenin marul ve salatalarin nitrat birikimi üzerine etkisi. VI. Türkiye Ulusal Bahçe Bitkileri Kongresi, 4-8 Ekim, Şanlıurfa.

Özkan, N., Dağlığlu, M., Ünser, E., Müftüoğlu, N.M., 2016. Vermikompostun 1spanak (Spinacia oleracea L.) verimi ve bazı toprak özellikleri üzerine etkisi. Çanakkale Onsekiz Mart Üniversitesi Ziraat Fakültesi Dergisi, 4(1): $1-5$.

Pavloua, G.C., Ehaliotis, C.D., Kavvadiasa, V.A., 2007. Effect of organic and inorganic fertilizers applied during successive crop seasons on growth and nitrate accumulation in lettuce. Scientia Horticulturae, 111(4): 319-325.

Pekşen, A., Yamaç, M., 2016. Atık mantar kompostu/substratının kullanım alanları - 1: Özellikleri ve önemi. Mantar Dergisi 7(1): 49-60. 
Polat, E., Onus, A.N., Demir, H., 2004. The effects of spent mushroom compost on yield and quality in lettuce growing. Mediterranean Agricultural Sciences, 17(2):149-154.

Santamaria, P., 2006. Nitrate in vegetables: toxicity, content, intake and EC regulation. Journal of the Science of Food and Agriculture, 86(1): 10-17.

Sarıbaş, H.Ş., Uzun, S., 2019. A model to determine quantitative effects of light and temperature on organic tomato seedlings. Acta Sci. Pol. Hortorum Cultus, 18(3), 175-185.

Sarıbaş, H.Ş., Saka, A.K., Özer, H., 2018. Mathematical growth model for organically grown pepper transplants. Biological Agriculture \& Horticulture, 34(1): 10-17.

Singh, A.D., Abdullah, N., Vikineswary, S., 2003. Optimizaton of extraction of bulk enzymes from spent mushroom compost. J. Chem. Technol. Botechnol. 78: 743-752.

Taiz, L., Zeiger, E., 2008. Plant physiology. 4th ed. Sunderland, MA: Sinauer Associates.

Uzun, S., 2007. The effect of temperature and mean cumulative daily light intensity on fruiting behavior of greenhousegrown tomato. J Am Soc Hortic Sci. 132(4):459-466.

Vural, H., Eşiyok, D., Duman, İ., 2000. Kültür Sebzeleri (Sebze Yetiştirme). Ege Üniversitesi, Ziraat Fakültesi, Bornova-İzmir. 